\title{
DEVALAKSHMIDEVI IN THE MEDIEVAL HISTORY OF NEPAL
}

\author{
Basudevlal Das \\ Department of History, TU, Thakur Ram Multiple Campus, Birgunj, Nepal \\ E-mail: basudevlaldas@gmail.com
}

\begin{abstract}
Devalakshmidevi was a dauther of king Jayatungamalla of Kathmandu valley. She was married with king Harisinghadeva, the last king of Karnata Dynasty in Mithila. In those days, the capital of Mithila was Simaraungarh, which is at present in Bara district, Narayani Zone of Nepal. In 1326 A.D. Ghiyas-uddin Tughlaq, the Turk emperor of Delhi, invaded his kingdom of Mithila. After the downfall of the capital, king Harisinghadeva departed towards Kathmandu valley with his family but he died in the way. Then his wife and other members of his family entered into valley as an honourable guests. Queen Devalakshmidevi lived in Yuthunima palace where her brother Jayarudramalla was the king. After the death of Jayarudramalla the political situation of the palace became very critical and by her abilities and qualities, Devalakshmidevi became able to establish her control over the rule and administration of the valley during the long period of thirty years from 1336 A.D. to 1366 A.D. Thus, she appears as a very influential personality in the history of medieval Nepal.
\end{abstract}

\section{Key words}

Jayatungamalla; Harisinghadeva; Karnata Dynasty; Rajyalakshmidevi; Jayasthitimalla

\section{Introduction}

Several examples that women have influenced the rule and administration can be seen in the history of the world. In many ways they have turned the waves of history. There is something in a woman beyond all human delight: a magnetic virtue, a charming quality, an occult and powerful motive (Burton, 1958). In the history of medieval Nepal a brilliant woman had played an important role in rule and administration. She was Devalakshmidevi.

The name of Devalakshmidevi is found as Devaladevi in several sources. She was daughter of king Jayatungamalla of Kathmandu and Queen Padmalakshmidevi (Padumalladevi) (Shaha, 1992). She was born in 1300 A.D (Nepal, 2054 BS). She was married with Harisinghadeva, the last king of 
Karnata Dynasty in Mithila (Khanal, 2027 BS). In a source it is narrated that Harisinghadeva was born in 1294 A.D. and enthroned in 1307 A.D. According to that very source he was at the age of twenty when married (Nepal, 2054 BS). Towards 1310 A.D. the army of king Harisinghadeva invaded Kathmandu valley (Das, 2013). In negotiation to come to a compromise with Chandeswar Thakkur, the conqueror Mahamatya (Prime minister) of king Harisinghadeva who was then leading the army of Mithila, king Jayatungamalla had given his beautiful daughter Devalakshmidevi to the hands of enthroned king Harisinghadeva of Mithila (Nepal, 2054 BS).

\section{Circumstances in Kathmandu Valley}

In the month of January of 1326 A.D. king Harisinghadeva departed with his family towards Kathandu valley after the downfall of his capital Simaraungarh when Ghiyasud-din Tughlaq, the Turk emperor of Delhi, invaded his kingdom of Mithila (Vaidya, 1999). The ruins of the capital are located at present in Simaraungarh area in Bara district, Narayani Zone.The king of Kathmandu Jayarudramalla invited these persons to come to him knowing the incident occurred in the capital of Mithila. Jayarudramalla was son of Jayatungamalla. King Harisinghadeva died on the way. His wife Queen Devalakshmidevi and son prince Jagatsinghadeva along with other persons entered into the Kathmandu valley as the honourable guests (Shaha, 1992). Queen Devalakshmidevi lived in Yuthunima palace at Bhaktapur with her brother king Jayarudramalla (Vaidya, 1999). King Jayarudramalla breathed his last within six months of the entrance of Queen Devalakshmidevi into Bhaktapur. Bhaktapur was the then capital of Kathmandu valley kingdom. King Jayarudramalla died in the monthe of July, 1326 A.D. in the date of Vikrama Samvat 1383, Ashadha Shukla Paksha Purnima Tithi (Nepal, 2054 BS). His four queens set fire on their bodies and bebame Sati after his death. He had two sons namely Tribhuvanamalla and
Viramalla who had died before him. His heir was only his daughter princess Nayakadevi. The nurturing of princess Nayakadevi was done jointly by her Pitamahi (grandmother) Padmalakshmidevi and new comer Phupu (fathers's sister) Devalakshmidevi. In this way princess Nayakadevi was the first woman successor of the throne in the history of Nepal (Nepal, 2054 BS).

According to the wills of the influential Phupu Devalakshmidevi and Pitamahi Padmalakshmidevi a suitable bridegroom for princess Nayakadevi was searched and she was married in 1329 A.D. with prince Harishchandra, a descendant of the king of Kashi, who was brought to be a son-in-law (Nepal, 2054 BS). Prince Harishchandra faced some disputes because the courtiers were not unanimous on this marriage settlement (Shaha, 1992). In the month of July, 1332 A.D. Padmalakshmidevidied at herage of sixtyseven (Nepal, 2054 BS). Her death generated many problems to prince Harishchandra in keeping his position safe in the palace. Finally he was poisoned to death in the month of May, 1335 A.D. (Shaha, 1992). Princess Nayakadevi was not sent to be Sati because she was successor of the throne. After this, prince Gopalachandra, the younger brother of late prince Harishchandra, endeavoured to capture the rule accepting his Bhauju (elder brother's wife). But Devalakshmidevi wanted to bring her own son prince Jagatasinghadeva to the power with the help of some courtiers (Nepal, 2054 BS).

There was rivalry for the power between prince Gopalachandra, the patron Devara (husband's younger brother) of princess Nayakadevi and prince Jagatasinghadeva of Mithila. (Shaha, 1992). Prince Jagatasinghadeva was son of late king Harisinghadeva, the last Karnata king of Mithila and Queen Devalakshmidevi (Petech, 1984). In the month of July, 1335 A.D. prince Gopalachandra tried to enter into the Yuthunima palace along with his group. After this, a violent struggle had taken place which resulted into the death of twelve persons from 
both of the rival groups. After some months' discussion, both the rival groups had come to harmony and prince Gopalachandra had obtained the right to rule in the name of princess Nayakadevi. But Devalakshmidevi, the authority of the Yuthunima palace, was not convinced on this arrangement. She wanted princess Nayakadevi to keep in hands of her own son prince Jagatasinghadeva and thus the confirmation of his authority also (Nepal, 2054 BS).

\section{Rise in power and position}

Devalakshmidevi took some of the courtiers in her hands. In 1336 A.D. the effective courtiers like Anekaram Mahatha and Abhayaram Mulmi agreed to act being loyal to her. This was her big tact and achievement. In 1337 A.D. her supporter-courtiers had established their control over the opponent courtiers. Prince Gopalachadra was assassinated in December, 1339 A.D. His assassination paved the way for enjoying the monopoly of Devalakshmidevi and prince Jagatasinghadeva in the then court-affairs. Finally this incident led to the love-marriage between princess Nayakadevi and prince Jagatasinghadeva (Nepal, 2054 BS).

Though some courtiers were opposing prince Jagatasinghadeva in rule, in January, 1342 A.D. Devalakshmidevi had established the control over the revolt of Nuvakota (Nepal, 2054 BS). In January, 1347 A.D., Pausha Krishna Paksha Dashami Tithi princess Nayakadevi and prince Jagatasinghadeva gave birth to a daughter named Rajyalakshmidevi (also mentioned as Rajalladevi). Princess Nayakadevi breathed her last only after ten days of her daughter's birth (Shaha, 1992). Subsequently, it seems that the situation of the palace had become uncontrolled. Prince Jagatasinghadeva was imprisoned. After the imprisonment his name was not mentioned anywhere, so it was guessed that he died in prison. The newly born heir princess Rajyalakshmidevi was entirely depended on Pitamahi (grandmother)
Devalakshmidevi for her nurturing (Nepal, 2054 BS).

Devalakshmidevi was daughter of late king Jayatungamalla and sister of late king Jayarudramalla. Princess Nayakadevi was daughter of Jayarudramalla. Prince Jagatasinghadeva was son of Devalakshmidevi. Thus princess Nayakadevi and prince Jagatasinghadeva were kins among themselves as cousins (Mama-Cheli and Phupu-Chela). So, their cohabitation is even under the marks of interrogation (Shaha, 1992). But in SouthIndian regions the cousins are entitled to this effect where their cohabitation is lawful. We know that prince Jagatasinghadeva was son of Harisinghadeva, the last king of Karnata Dynasty of Mithila, originally and historically belonging to Karnata Desh of South India. In Nepal also marriage with Mama-Cheli (maternal uncle's dauthers) is prevalent in some castes like Thakuri and Magar. Thus it is obvious by this event that in those days the system of this very kind was prevalent here (Nepal, 2054 BS).

In 1344 A.D. king Jayarimalla, the ruler of Tripura palace, died. He had no heir, so there was no ruler for coming three years. The Tripura palace was passing through a critical condition during the rise of prince Jagatasinghadeva. Devalakshmidevi had become successful to reestablish her power in 1347 A.D. (Shaha, 1992). In the same year, according to her consent, king Jayarajadeva was enthroned on Devapatan (Nepal, 2054 BS).

Nurturing the newly born princess Rajyalakshmidevi, Devalakshmidevi established her control over rule and administration. She step-by-step brought under her control the dereriorated condition of the palace which had ended her son. She succeeded in imprisoning an effective rebel named Pashupatimalla in 1348 A.D. She consolidated her power and influence by keeping close contacts with other powerful courtiers and feudatories in the valley 
(Shaha, 1992). In 1349 A.D. the army of Hazi Samasuddin Iliyas invaded in Katyhmandu valley and caused the havoc through plunder and sabotaging activities throughout a week (Nepal, 2054 BS). Subsequently some internal struggles also grew in the valley. She effectively suppressed those struggles. She is appeared with the epithet "Vijayarajye" (triumphant) in Vanshavali (Shaha, 1992). She was such powerful that the epithet like "Rajadhiraja Parameshvara Paramabhattaraka" (the king of kings almighty supreme honourable) were her adornments though king Jayarajadeva himself was on the throne (Nepal, 2054 BS). In fact she was de-facto ruler in the Kathmandu valley.

Devalakshmidevi sent her people towards Madhesa (mid-region) to search a suitable bridegroom for her grand-daughter princess Rajyalakshmidevi. From DakshinaMadhesa (south mid-region) a person named Jayasthitimalla was brought as the bridegroom in September, 1354 A.D. Princess Rajyalakshmidevi of eight years of age was married with Jayasthitimalla of nine years of age in Januyary,1355 A.D. King Jayasthitimalla (also mentioned as Sthitimalla or Sthitirajamalla) had become effective in the rule of Kathmandu valley (the then Nepal) by the capacity of the husband of princess Rajyalakshmidevi (Nepal, 2054 BS).

\section{Conclusion}

A princess of Kathmandu Valley and the queen of king Harisinghadeva of Mithila, Devalakshmidevi entered Bhaktapur with her family in 1326 A.D. after the downfall of her kingdom of Mithila and capital Simaraungarh. In a description it is narrated that king Harisinghadeva sent her with his son prince Jagatasinghadeva to seek military assistance to regain his lost kingdom by the help of his relatives, the Nepalese rulers (Khanal, 2056 BS). But because king Harisinghadeva died on the way, it seems not proper to have such. On the other hand, Devalakshmidevi had respectfully come to her maternal or paternal home to live with her son and others. Her personality was enriched with abundant brilliance. She, from the very beginning, played an important role in the politics of Kathmandu valley. When she came to Bhaktapur, king Jayarudramalla (her elder brother) died in that very year. She helped her mother Padmalakshmidevi in nurturing the heir princess Nayakadevi, the only daughter of her elder brother. She became more influential when her mother Padmalakshmidevi died in 1332 A.D. She reached high as supreme authority and only powerful person in the rule and administration after the death of prince Harishchandra, the husband of princess Nayakadevi in 1335 A.D. She played an active role in the politics of Kathmandu valley from 1336 A.D. till her death in 1366 A.D., during the long thirty years (Vaidya, 1999). In this way, Devalakshmidevi had very important place in the medieval history of Nepal.

\section{References}

Burton, R. (1958). The Anatomy of Melancholy. In S. Burton (ed.), The Home Book of Quotations: Classical and Modern, Part III, (p. 2184). New York: Dodd, Mead \& Company.

Das, B. (2013). Mithilako Rajanaitika Itihasa. Birgunj: Bharati Nilaya.

Khanal, M.P. (2027 BS). Itihasa Sansodhanako Kehi Sansodhana. Ancient Nepal,13, 45-47.

(2056 BS). Simaraungarhko Itihasa. Kathmandu: Nepal Ra Ashiyali Anusandhana Kendra, Tribhuvan University.

Nepal, G.M. (2054 BS). Nepalako Purvamadhyakalako Itihasa. Kathmandu: Nepal Ra Ashiyali Anusandhana Kendra, Tribhuvan University.

Petech, L. (1984). Medieval History of Nepal. Rome: Instituto Italiano.

Shaha, R. (1992). Ancient and Medieval Nepal. New Delhi: Manohar Publishers and Distributors.

Vaidya, T.R. (1999). History of Simaraungarh. Voice of History, Vol. 14, (1), 14-16. 